\title{
Diesel and CNG Transit Bus Emissions Characterization By Two Chassis Dynamometer Laboratories: Results And Issues
}

\author{
Nigel N. Clark, Mridul Gautam, Byron L. Rapp and Donald W. Lyons \\ West Virginia Univ. \\ Michael S. Graboski, Robert L. McCormick and Teresa L. Alleman \\ Colorado School of Mines \\ Paul Norton \\ National Renewable Energy Laboratory
}

Reprinted From: Topics in General Emissions

(SP-1459)

The Engineering Society For Advancing Mobility Land Sea Air and Space INTERNATIONAL
International Spring Fuels \& Lubricants Meeting \& Exposition Dearborn, Michigan May 3-6, 1999 
The appearance of the ISSN codeat the bottom of this page indicates SAEsconsent that copies of the papermaybe made forpersonal orintemal use of specificctients. Thisconsent is given on the condition however, that the copier pay a $\$ 7.00$ per article copy fee through the Copyright Clearance Center, Inc. Operations Center, 222 Rosewood Drive, Danvers, MA 01923 for copying beyond that permitted by Sections 107 or 108 of the U.S. Copyright Law. Thisconsent does not extend to otherkinds of copyingsuch as copying for general distribution, foradvertising orpromotional pumoses, for creating new collective works, or for resale.

SAE routinely stocks printed papers for a period of three years following date of publication. Directyour orders to SAE Customer Sales andSatisfaction Department.

Quantity reprintrates can beobtained from the CustomerSales and Satisfaction Department.

To request permission to reprinta technical paperorpermission to use copyrighted SAE publications in otherworks, contact the SAE Publications Group.

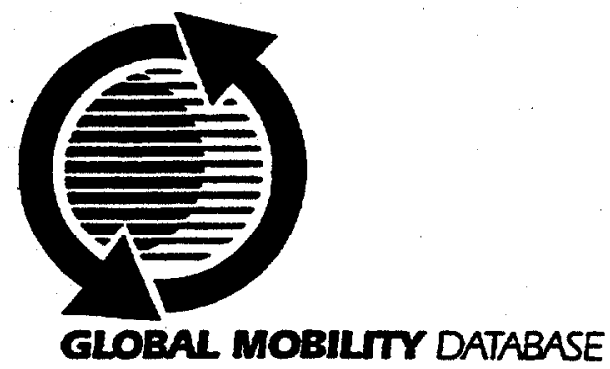

All SAE papers, standards, and selected booksareabstractedandindexedin the SAE GlobalMobility Database.

No part of this publication may by reproduced in any form, in an electronic retrieval system or otherwise, without the prior written permission of the publisher.

\section{SSN0148-7191}

Copyright e1999 Society of Automotive Engineers, inc.

Positionsandopinions advancedin this paperare those of the author(s) and notnecessarity those of SAE. Theauthor is solely responsiblefor the content of the paper. Aprocess is available by which discussions will be printed with the paper if it is published in SAE Transactions. For permission to publish this paper in full or in part, contact the SAE Publications Group.

Personswishing to submit papers to beconsidered forpresentation orpublication through SAE should send the manuscript or a 300 word abstract of a proposed manuscript to: Secretary, Engineering Meetings Board, SAE. 


\title{
Diesel and CNG Transit Bus Emissions Characterization By Two Chassis Dynamometer Laboratories: Results And Issues
}

\author{
Nigel N. Clark, Mridul Gautam, Byron L. Rapp and Donald W. Lyons \\ West Virginia Univ.
}

Michael S. Graboski, Robert L. McCormick and Teresa L. Alleman
Colorado School of Mines

Paul Norton

National Renewable Energy Laboratory

Copyright $(1999$ Society of Automotive Engineers, Inc.

\section{ABSTRACT}

Emissions of six 32 passenger transit buses were characterized using one of the West Virginia University (WVU) Transportable Heavy Duty Emissions Testing Laboratories, and the fixed base chassis dynamometer at the Colorado Institute for Fuels and High Altitude Engine Research (CIFER). Three of the buses were powered with

97 ISB 5.9 liter Cummins diesel engines, and three were .uwered with the 19975.9 liter Cummins natural gas (NG) counterpart. The NG engines were LEV certified. Objectives were to contrast the emissions performance of the diesel and NG units, and to compare results from the two laboratories. Both laboratories found that oxides of nitrogen and particulate matter (PM) emissions were substantially lower for the natural gas buses than for the diesel buses. It was observed that by varying the rapidity of pedal movement during accelerations in the Central Business District cycle (CBD), CO and PM emissions from the diesel buses could be varied by a factor of three or more. The driving styles may be characterized as aggressive and non-aggressive, but both styles followed the CBD speed command acceptably. PM emissions were far higher for the aggressive driving style. For the NG fueled vehicles driving style had a similar, although smaller, effect on $\mathrm{NO}_{\mathrm{x}}$. It is evident that driver habits may cause substantial deviation in emissions for the CBD cycle. When the CO emissions are used as a surrogate for driver aggression, a regression analysis shows that $\mathrm{NO}_{\mathrm{x}}$ and $\mathrm{PM}$ emissions from the two laboratories agree closely for equivalent driving style. Implications of driver habit for emissions inventories and regulations are briefly considered.

\section{INTRODUCTION}

Spark ignited natural gas engines offer an attractive ernative to diesel engines for powering urban buses because tney have been shown to offer lower oxides of nitrogen $\left(\mathrm{NO}_{\mathrm{x}}\right)$ and particulate matter (PM) emissions. This is of particular relevance in high altitude operation where some diesel control strategies will produce higher PM due to the deprivation of oxygen mass in the cylinders. The study reported in this paper had two functions, namely (1) to compare the emissions from natural gas and diesel transit buses in service in Boulder, Colorado and (2) to compare the emissions measurements from two separate chassis dynamometer laboratories. These were one of the WVU Transportable Heavy Duty Vehicle Emissions Testing Laboratories, and the fixed base chassis dynamometer laboratory of CIFER, a research institute at the Colorado School of Mines.

\section{LITERATURE}

HEAVY-DUTY VEHICLE EMISSIONS. Exhaust emissions from heavy-duty engines in the United States are regulated by the EPA through the Clean Air Act. Rather than regulating emissions from the vehicles themselves, engines are tested by the manufacturers using the Federal Test Procedure. This test involves running the engine on a dynamometer over a range of load and speed set points (the transient test cycle) while measuring the emissions of regulated pollutants: hydrocarbons ( $\mathrm{HC})$, carbon monoxide (CO), nitrogen oxides $\left(\mathrm{NO}_{\mathrm{x}}\right)$, and total particulate matter $(\mathrm{PM})$. The relationship between engine certification emissions and in-use vehicle emissions is unclear although engine certification data are still used for emissions inventory projection. Hence, it is necessary to perform studies to measure pollutant emissions directly from vehicles. Although chassis tests cycles exist, procedures for vehicle testing are not rigorously standardized. In the present work, we compare emissions measurements for six vehicles from two different laboratories. The test results are expected to add to our understanding of facility-to-facility variability in heavy-duty chassis dynamometer testing. Little comprehensive information is available on variations between laboratories. Kittelson and Johnson [1] have highlighted effects of dilution tunnel configurations, but these cannot be 
applied readily to predicting contributions to variation between laboratories.

NATURAL GAS VEHICLE EMISSIONS. All of the natural gas technology discussed below employs lean burn fueling to minimize the in-cylinder production of $\mathrm{NO}_{\mathrm{x}}$. In a previous study [2], school buses in California powered by Cummins 8.3 liter natural gas engines returned $12 \%$ less $\mathrm{NO}_{\mathrm{x}}$ and $61 \%$ less PM than similar buses powered by Cummins 8.3 liter diesel engines. These natural gas engines employed closed loop fueling management. Two other studies of 40 foot transit buses $[3,4]$ also revealed the benefits of natural gas as a fuel with recent spark ignited engine technologies. The Detroit Diesel Series $50 \mathrm{G}$ natural gas powered buses (open loop fueling control) produced, on average, only $20.8 \mathrm{~g} / \mathrm{mile}$ of $\mathrm{NO}_{\mathrm{x}}$ and $0.025 \mathrm{~g} / \mathrm{mile}$ of PM over the Central Business District (CBD) cycle. This compares with $31.5 \mathrm{~g} / \mathrm{mile}$ of $\mathrm{NO}_{\mathrm{x}}$ and $0.66 \mathrm{~g} / \mathrm{mile}$ of PM for the diesel Detroit Diesel Series 50 powered buses. In the case of Cummins L10 natural gas (closed loop fueling control) and Cummins M11 diesel powered buses, the natural gas buses yielded $23.5 \mathrm{~g} / \mathrm{mile}$ of $\mathrm{NO}_{\mathrm{x}}$ and $0.030 \mathrm{~g} / \mathrm{mile} \mathrm{PM}$, compared with $28.7 \mathrm{~g} / \mathrm{mile} \mathrm{NO}_{\mathrm{x}}$ and $0.69 \mathrm{~g} / \mathrm{mile}$ PM for the diesel buses.

EFFECT OF CYCLES. Prior research has shown that the chassis dynamometer cycle employed to evaluate emissions can have a profound effect on the emissions results, expressed in g/mile. Graboski and coworkers [5] conducted a study of emissions from 21 vehicles in the Northern Front Range Area of Colorado, and concluded that the CBD cycle yielded higher emissions from diesel vehicles $\mathrm{NO}_{\mathrm{x}} 21.0$ g/mile; PM $2.85 \mathrm{~g} /$ mile average for test vehicles) than the cycle known as the 5 Peak Cycle or West Virginia Truck Cycle (17.8 g/mile $\left.\mathrm{NO}_{\mathrm{x}} ; 1.24 \mathrm{~g} / \mathrm{mile} \mathrm{PM}\right)$. In separate testing of a 40 foot diesel transit bus by WVU [4], the CBD cycle yielded $32.2 \mathrm{~g} / \mathrm{mile}^{\mathrm{NO}} \mathrm{x}_{\mathrm{x}}$ and $0.22 \mathrm{~g} / \mathrm{mile} \mathrm{PM}$, while the 5 peak cycle yielded $28.6 \mathrm{~g} / \mathrm{mile} \mathrm{NO}_{\mathrm{x}}$ and $0.08 \mathrm{~g} / \mathrm{mile} \mathrm{PM}$. In addition this transit bus was run through the 5 mile route, which is similar to the 5 peak cycle, but demands full power accelerations [6]. This demand for full power acceleration has a tendency to affect the PM production more than $\mathrm{NO}_{\mathrm{x}}$ production: in the case of the transit bus the 5 mile route emissions were $24.7 \mathrm{~g} / \mathrm{mile} \mathrm{NO}_{\mathrm{x}}$ and $0.17 \mathrm{~g} /$ mile $\mathrm{PM}$. The present study of transit buses employs the CBD cycle.

\section{EXPERMENTAL METHODS}

DESCRIPTION OF WVU LABORATORY. West Virginia University operates two Transportable Heavy Duty Vehicle Emissions Testing Laboratories that conduct truck and bus emissions characterization at locations throughout the USA. Each laboratory includes a semi-trailer carrying a chassis dynamometer system. This trailer is transported to a site and lowered to the ground to facilitate testing. The test vehicles are driven on to the 12.6 inch rolls located in the semi-trailer frame, and both single drive axle and tandem axle vehicles can be accommodated. Power is taken from the vehicle hubs, rather than through the rollers, so that tire slip is avoided. Driveshafts carry the axle torque through torque cells to speed-increasing transmissions that drive sets of flywheels and Mustang eddy current power absorbers on each side of the test vehicle. In the case of the small transit buses used in the present program, only one set of flywheels and one power absorber were used. The simulated test inertia weight was $17,914 \mathrm{lb}$. Further details of the laboratory construction can be found in references $[7,8]$.

The vehicle speed is controlled by a driver responding to a driver's aid screen. A single objective speed line is used by WVU and the driver is instructed to follow the line as closely as possible. WVU also conducts regular testing using "routes" rather than cycles: in this case maximum acceleration is demanded during certain acceleration portions of the test schedule, and the driver is prompted by a step rise in speed that the driver must then try to attain [6].

The whole vehicle exhaust stream is routed to a full scale dilution tunnel, with flow controlled by two fans in series drawing through an adjustable critical venturi system. Heated probes and lines convey sample flows to research grade instrumentation, as described in Table 1 . All $\mathrm{NO}_{\mathrm{x}}$ emissions were corrected to standard humidity. Methane and nonmethane hydrocarbon levels were determined using bag samples shipped to the WVU chromatograph laboratory.

Table 1. Analyzers used by the WVU laboratory for emissions measurement

\begin{tabular}{|c|c|c|}
\hline $\mathrm{HC}$ & $\begin{array}{l}\text { Flame ionization } \\
\text { detector }\end{array}$ & $\begin{array}{l}\text { Rosemount Analytical } \\
\text { Model } 402\end{array}$ \\
\hline $\mathrm{CO}$ & $\begin{array}{l}\text { Non-dispersive } \\
\text { infrared }\end{array}$ & $\begin{array}{l}\text { Rosemount Analytical } \\
\text { Model 880A }\end{array}$ \\
\hline $\mathrm{CO}_{2}$ & $\begin{array}{l}\text { Non-dispersive } \\
\text { infrared }\end{array}$ & $\begin{array}{l}\text { Rosemount Analytical } \\
\text { Model 880A }\end{array}$ \\
\hline $\mathrm{NO}_{\mathrm{x}}$ & Chemiluminescent & $\begin{array}{l}\text { Rosemount Analytical } \\
\text { Model } 955\end{array}$ \\
\hline NMHC & $\begin{array}{l}\text { Gas } \\
\text { Chromatograph }\end{array}$ & Varian 3600 \\
\hline
\end{tabular}

DESCRIPTION OF CIFER LABORATORY. The Colorado Institute for Fuels and Engines Research operates a fixed base chassis dynamometer laboratory in Denver, Colorado. The chassis dynamometer is suitable for operating at vehicle speeds up to $60 \mathrm{mph}$. The vehicles are driven on twin 40-inch rolls which spin at $500 \mathrm{rpm}$ at a road speed of 60 mph. The DC dynamometer is located 90 degrees to the rolls and shaft power is transmitted through two 5:1 ratio Falk gearboxes. An inline torque meter is located on the dynamometer shaft and reads the dynamometer load. Inertia is simulated with mechanical flywheels located on the highspeed dynamometer shaft. Up to 55,000 pounds of inertia can be simulated in increments of 2,500 pounds. The inertial weight was set at $17,914 \mathrm{lb}$ for this test program. Load simulation for running friction is accomplished with control circuitry to vary the dynamometer applied load in response to the vehicle speed. Vehicle wind and rolling friction losses are estimated from published studies [9] and the dynamometer controller is operated to provide the appropriate control of torque at the rolls based upon weight and frontal area.

The vehicle speed is managed by the vehicle driver. cycle is displayed for using a driver's aid prompt that shows current speed and approximately 30 seconds into the future to 
anticipate shifting. For quality control purposes, $\pm 2 \mathrm{mph}$ error bands are displayed for the driver. A single driver was used for all chassis testing performed under this program, except that the WVU driver operated one set of runs on the CIFER moratory.

The system for diesel emissions measurement (THC, $\mathrm{CO}, \mathrm{NO}_{\mathrm{x}}$, and $\mathrm{PM}$ ) includes supply of conditioned intake and dilution air, an exhaust dilution system, and capability for sampling particulate and analysis of gaseous emissions. All components of the system meet the requirements for heavyduty engine emissions certification testing as specified in Code of Federal Regulations 40, Part 86, Subpart N. The intake air conditioning, exhaust dilution, and emissions measurement systems have been described in more detail elsewhere $[4,10]$. Most CIFER tests were conducted with air

- temperature and humidity set as close as possible to the WVU test conditions. All $\mathrm{NO}_{\mathrm{x}}$ emissions were corrected to standard humidity using the Federal Test Procedure adjustment factor. $\mathrm{PM}$ and $\mathrm{CO}$ emissions were not corrected for humidity. Carbon dioxide emissions are also measured using a Pierburg NDIR and used to calculate fuel economy.

NMHC analysis is performed on the proportionally sampled, dilute exhaust bag using a gas chromatograph (GC) method. After the bag is analyzed for THC by the heated FID at the conclusion of the test, a stainless steel bellows pump is used to transfer a sample directly into the gas-sampling valve in the GC. A background sample from the background bag is also transferred directly into the GC gas-sampling valve. The

GC method employed for this analysis is described in Hewlett" card Application Note 228-125. The NMHC emission is rmined from bagged exhaust samples as the sum of the speciated NMHC.

TEST CYCLES. In this study, the bulk of the research was performed using the CBD cycle found in SAE Recommended Practice J1376. It may be argued that this cycle mimics the use of a bus on an urban route. It may err in requiring less than full power on acceleration to follow the speed versus time trace that is presented to the driver. In addition, some comparative testing was performed between the laboratories using full power acceleration in the following fashion. WVU conducted tests using the 5 mile route [6], which employs maximum acceleration but is held to a 5 mile distance by adjusting the cruise sections in real time. At the time of comparative testing, the CIFER laboratory did not have the realtime route drivers aid programmed, and instead employed the 5 peak cycle, from which the 5 mile route was derived [6], and instructed the driver to accelerate at full power. In this way, a greater distance, close to 5.5 miles, was completed during CIFER testing. Data were compared between the WVU 5 mile route and the CIFER full power variation of the as peak cycle, assuming the overall test sequences to be sufficiently similar in execution.

TEST VEHICLES. GO Boulder is an office of the City of Boulder, Colorado that is devoted to alternative modes of transportation. In 1989, GO Boulder, in conjunction with the Regional Transportation District (RTD), devised plans for a new transit demonstration project, dubbed the HOP. The HOP is a frequent, small-bus shuttle service that connects Boulder's core activity areas in a loop route. The objectives of the HOP include environmental preservation through reduced air pollution, reduced traffic congestion, and reduced need for roadway expansion. Since its introduction in 1994, the HOP's rider-ship has exceeded all expectations. Based on the success of the HOP, GO Boulder is now launching the "SKIP". The SKIP buses are similar to the HOP, except that a portion of them will run on CNG. A description of the buses is given in Table 2. In the present program, three diesel buses and three compressed natural gas (CNG) buses were subjected to testing. Specific data for the buses tested are listed in Table 3. Cummins presently offers LEV and ULEV versions of the B5.9G engine, as well as a version certified to the 1997 heavyduty engine standard. The natural gas engines tested in this study were certified as LEV under the Clean Fuel Fleet Program.

Table 2: Information on the Boulder Colorado Skip buses.

\begin{tabular}{ll|}
\hline Bus: & World Trans 3000 \\
Length: & $26^{\prime} 5^{\prime \prime}$ \\
Floor Height: & $25^{\prime \prime}$ \\
Capacity: & 22 passengers seated, 10 passengers \\
& standing, 2 wheelchair positions \\
Manufacturer: & World Trans in Newton, Kansas \\
Curb Weight: & $14,525 \mathrm{lb}$ \\
Gross Vehicle Weight: & $18,780 \mathrm{lb}$ \\
Engines: & Cummins CSB5.9 and B5.9G \\
Configuration: & In-line, 6 cylinder \\
Displacement: & 5.9 liters \\
Turbocharged/Air to air after-cooled \\
Horsepower: & 175 hp diesel \\
Horsepower: & 195 hp natural gas \\
Exhaust conditioning: & Nelson Integrated Muffler/Catalyst \\
\hline
\end{tabular}

Table 3. Description of Cummins Powered GO Boulder/RTD SKIP Buses.

\begin{tabular}{|l|c|c|c|c|c|c|}
\hline License Plate & 1010 & 1011 & 1012 & 1013 & 1014 & 1015 \\
\hline Fuel & Diesel & Diesel & Diesel & CNG & CNG & CNG \\
\hline Odometer & 18,672 & 18,751 & 27,111 & 12,918 & 9,410 & 14,833 \\
\hline Engine & CSB-175 & CSB-175 & CSB-175 & B5.9-195G & B5.9-195G & B5.9-195G \\
\hline Year & 1997 & 1997 & 1997 & 1997 & 1997 & 1997 \\
\hline Engine Family & VCE359DJDARA & VCE359DJDARA & VCE359DJDARA & VCE359D1CAAA & VCE359D1CAAA VCE359DICAAA \\
\hline Chassis Model & World Trans & World Trans & World Trans & World Trans & World Trans & World Trans \\
& Bu A 045 & Bu A 045 & Bu A 045 & CAP Bu & CAP Bu & CAP Bu \\
\hline & 4LMKB3312UL0 & 4LMKB3314VL0 & 4LMKB3316VL0 & 4LMLB3312VL0 & 4LMLB3314VL0 & 4LMKB3316 \\
& 00277 & 00278 & 00279 & 00266 & 00293 & VL000294 \\
\hline Note: & Catalyst & Catalyst & Catalyst & Catalyst & Catalyst & Catalyst \\
\hline
\end{tabular}

The three CNG bus engines were LEV certified, however when bus 1015 was tested by WVU it was temporarily not equipped with a catalyst. 


\section{RESULTS}

INTER-LABORATORY COMPARISONS. A number of checks were performed to insure that the two laboratories were making comparable measurements. As noted, WVU utilized ambient air as the intake to the engine and subsequently, when the vehicles were tested by CIFER, the intake air temperature and humidity were set to the values employed by WVU. Each laboratory analyzed span gases from the other laboratory. In each case, the laboratory spanned the appropriate meter using their in-house standard. Then, the gas from the second laboratory was read and results were compared. Within the $\pm 1 \%$ accuracy of the gases themselves, the emissions systems of the two laboratories agreed quantitatively. Exhaust bag samples were also collected and analyzed by both laboratories. For both raw and dilute exhaust bags acceptable agreement was obtained.

Applied road load was compared for the two laboratories. At $20 \mathrm{mph}$ for bus 1011 , WVU utilized a wind and tire friction load of $12 \mathrm{bhp}$. CIFER inputted $38.76 \mathrm{ft}-\mathrm{lb}$ at $20 \mathrm{mph}$ resulting in $6.2 \mathrm{bhp}$., in addition with a load of 29.54 $\mathrm{ft}-\mathrm{lb}$ from the dynamometer friction not indicated by the torque meter at $20 \mathrm{mph}$. Thus, the total load applied by CIFER at $20 \mathrm{mph}$ was $10.8 \mathrm{bhp}$. The indicated difference of $1.2 \mathrm{bhp}$ is not significant considering that both systems attempt to apply this value at $20 \mathrm{mph}$ by feedback control and that the load associated with acceleration far outweighs the road load. Additionally, bus 1011 was driven by WVU through the 5mile route and bus 1012 was driven by CIFER through the WVU five mode test. WVU drove the five-mode as exactly a five mile route with free accelerations. CIFER drove the fivemode with free accelerations, but as the cycle. Thus, the miles accumulated for CIFER were 5.5. Speed during the free accelerations in the 5-mode test was compared for the two labs from 1 hertz data files (all cruise, deceleration, and idle points were deleted) and results are shown in the parity plot of Figure 1. This plot shows through bus accelerations that there is no difference in dynamometer loading between the two laboratories for accelerations from stop to between 20 and 40 $\mathrm{mph}$. There is some deviation from the parity line in the 0 to $20 \mathrm{mph}$ range, but it is not consistent from ramp to ramp and is probably caused by driver variability.

As a final inter-laboratory comparison, the CIFER driver drove on the WVU dynamometer and the WVU driver drove on the CIFER dynamometer. A comparison of CBD emissions results for bus 1012 for the two drivers on both dynamometers is shown in Table 4: Agreement for $\mathrm{NO}_{\mathrm{x}}$ is roughly $\pm 5 \%$ and for $\mathrm{PM}$ and $\mathrm{CO}$ is $\pm 10 \%$. Carbon dioxide emissions agree to roughly $3 \%$.

EMISSIONS TESTING RESULTS. Average CBD emissions are reported in the Appendix for both the WVU and CIFER laboratories. Data are included for both CIFER and WVU drivers on both dynamometers. Some tests are listed as aggressive or non-aggressive and this is explained below. Figure 2 shows the average emission rates initially measured by CIFER (aggressive cycles only) for the diesel and CNG powered buses, THC is reported for diesel and NMHC for
CNG. Figure 3 reports the same initial data for the WVU dynamometer (non-aggressive cycles only).

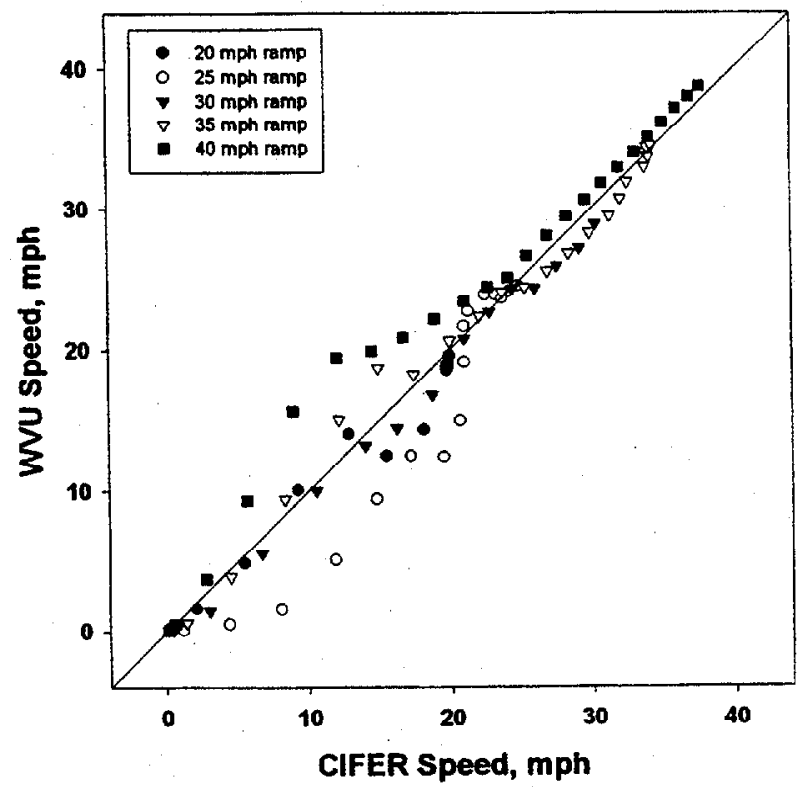

Figure 1. Parity plot comparing vehicle speed-time traces from WVU and CIFER during acceleration portions of the 5mode test.

Table 4. Driver comparison for diesel bus 1012, CBD cycle.

\begin{tabular}{|c|c|c|c|}
\hline & $\begin{array}{c}\text { WVU } \\
\text { Driver }\end{array}$ & $\begin{array}{c}\text { CIFER } \\
\text { Driver }\end{array}$ & \% Difference \\
\hline At WVU & & & \\
\hline $\mathrm{THC}$ & 0.30 & 0.35 & 15.4 \\
\hline $\mathrm{NO}_{\mathrm{x}}$ & 20.8 & 19.6 & 5.9 \\
\hline $\mathrm{CO}$ & 2.1 & 2.4 & 13.3 \\
\hline $\mathrm{CO}_{2}$ & 1743 & 1706 & 2.2 \\
\hline $\mathrm{PM}$ & 0.31 & 0.28 & 10.2 \\
\hline $\mathrm{AtCIFER}$ & & & \\
\hline THC & 0.15 & 0.14 & 2.8 \\
\hline $\mathrm{NO}$ & 18.8 & 18.5 & 1.6 \\
\hline $\mathrm{CO}$ & 7.2 & 6.5 & 9.3 \\
\hline $\mathrm{CO}_{2}$ & 1850 & 1784 & 3.6 \\
\hline $\mathrm{PM}$ & 0.57 & 0.51 & 10.2 \\
\hline
\end{tabular}

Emissions test results allow a comparison of nearly identical diesel and CNG powered vehicles. From an emissions standpoint, these LEV certified CNG vehicles have a significant advantage in all areas except NMHC. It was found that CNG PM emissions are only a small fraction of the PM emissions from the diesel vehicles. At CIFER, diesel PM averaged approximately $0.7 \mathrm{~g} / \mathrm{mi}$. while PM for the CNG buses was well below $0.1 \mathrm{~g} / \mathrm{mi}$. Diesel CO averaged $8.2 \mathrm{~g} / \mathrm{mi}$. and $\mathrm{CNG}$ averaged less than $0.3 \mathrm{~g} / \mathrm{mi}$. Emissions of $\mathrm{NO}_{\mathrm{x}}$ are also substantially lower for the CNG powered buses. $\mathrm{NO}_{\mathrm{x}}$ emissions averaged approximately $18.4 \mathrm{~g} / \mathrm{mi}$. for diesel and $11.2 \mathrm{~g} / \mathrm{mi}$. for CNG. NMHC speciation for the CNG vehicles indicated that ethane and propane make up more than $95 \%$ the NMHC, with the balance ethylene. Thus, CNG vehicl NMHC is of low reactivity in ozone formation [11] and is much less toxic than hydrocarbons in diesel exhaust. 
WVU findings are in agreement with CIFER laboratory findings. CNG has an advantage in all areas except for the NMHC. It was found that for the CNG buses, PM emissions te a small fraction of the PM emissions from the diesel buses. $\mathrm{VU}$ found that the (Non-aggressive driving) diesel PM averaged approximately $0.38 \mathrm{~g} / \mathrm{mi}$. while CNG PM was well below $0.1 \mathrm{~g} / \mathrm{mi}$. for the two buses tested with catalyst. In addition, diesel $\mathrm{CO}$ averaged $2.38 \mathrm{~g} / \mathrm{mi}$. while the $\mathrm{CNG}$ with catalyst averaged $0.39 \mathrm{~g} / \mathrm{mi}$. of $\mathrm{CO}$. CNG bus 1015 without the catalyst had $\mathrm{CO}$ emissions higher than the diesel buses at $8.25 \mathrm{~g} / \mathrm{mi}$. NMHC emissions were also substantially (perhaps a factor of four) higher for the bus tested without catalyst. Clearly, the catalyst is necessary for these CNG vehicles to achieve LEV emission levels. Note that a plot of emissions results for bus 1015, tested both with and without catalyst, is shown below in Figure 8. Emissions of $\mathrm{NO}_{x}$ are also substantially lower for the CNG powered buses. $\mathrm{NO}_{\mathrm{x}}$ emissions averaged approximately $20.6 \mathrm{~g} / \mathrm{mi}$. for diesel and $8.7 \mathrm{~g} / \mathrm{mi}$. for CNG.

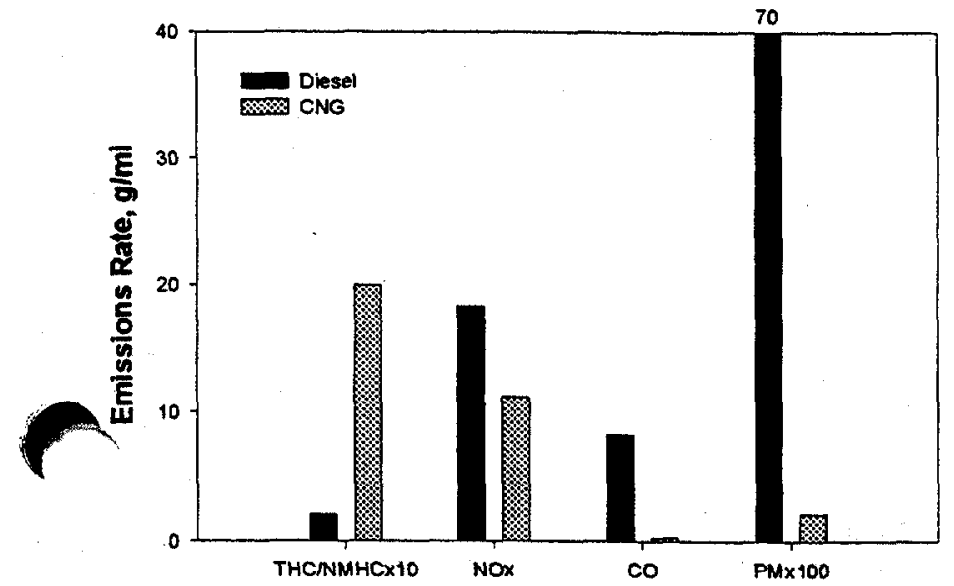

Figure 2. Comparison of average emission rates measured by CIFER (aggressive cycles) from diesel and CNG powered buses.

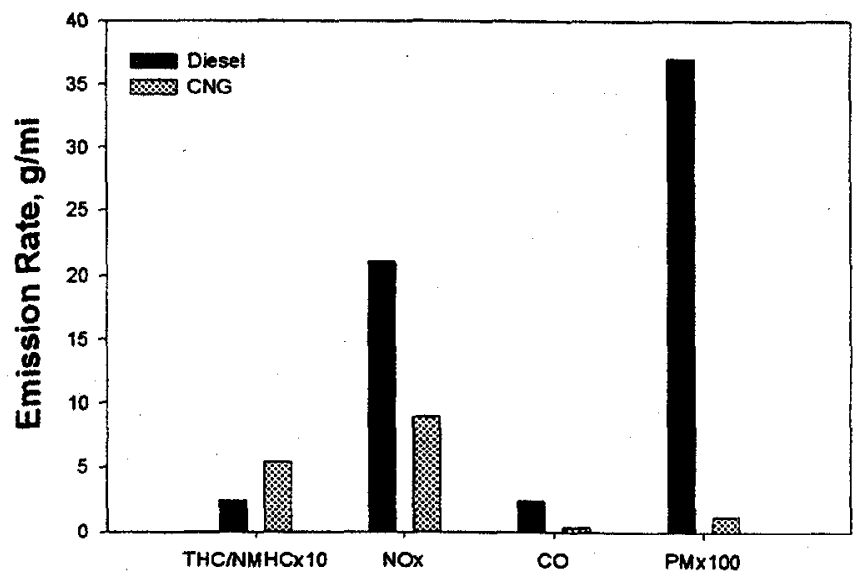

Figure 3. Comparison of average emission rates measured by WVU (non-aggressive cycles) from diesel and CNG powered buses. CNG average does not includes bus 1015 tested without catalyst.

For the diesel buses, the West Virginia transportable -ynamometer consistently measured higher $\mathrm{NO}_{\mathrm{x}}$, and lower $\mathrm{CO}$ and PM, when compared to CIFER. The researchers at both laboratories sought explanation for the difference, including an examination of intake and exhaust restrictions, and analysis of exhaust bags from the other laboratory. It was concluded that the difference was arising from synergy between two factors, namely:

1) The CO emissions of the diesel buses were highly nonlinear with respect to pedal behavior under high load conditions.

2) The different drivers aid screens at the two laboratories prompted different driver pedal behavior, although both screens legitimately portrayed the target cycles.

In the case of the WVU laboratory, a single line was displayed on the drivers aid screen and the driver was instructed to follow the line closely. In the case of the CIFER laboratory, the driver was required to remain between the two target lines ( $\pm 2 \mathrm{mph}$ ), thus giving the driver freedom to lag on some portions and lead in others. Within these constraints, the driver using the CIFER laboratory could demand occasional full power yielding high $\mathrm{CO}$ in a fashion that was nonlinear with the power demand. Diesel engine design usually provides for PM limited operation at full load, and increases in PM are associated with increasing rich zones in the cylinder and hence higher $\mathrm{CO}$ production.

This argument is supported by the observation that in the case of the natural gas fueled buses, the $\mathrm{CO}$ agreed well between laboratories, but the $\mathrm{NO}_{\mathrm{x}}$ was higher for the CIFER laboratory than the WVU measurements. Typical lean burn spark ignited natural gas control strategies would cause $\mathrm{NO}_{\mathrm{x}}$ to react to high loading, in a similar fashion to the $\mathrm{CO}$ behavior in diesel engines.

Data supporting these conclusions were obtained by asking the drivers at WVU and CIFER to drive the acceleration ramps in two modes. These were with normal aggression (his normal way of driving the cycle, aggressive at CIFER and non-aggressive at WVU), and the opposite approach. In the aggressive mode, the driver typically slightly over-accelerates the vehicle at the onset of acceleration and then lets up on the pedal at 10 to $15 \mathrm{mph}$ to match the trace requirement. In the non-aggressive or conservative mode, the driver tries to hold the pedal constant through the ramp, making any adjustment in pedal position slowly and smoothly.

This difference in acceleration technique causes the vehicle to operate in two distinct emissions modes. Figure 4 shows the emissions of carbon monoxide for the two modes of driving for bus 1010 . In the non-aggressive mode, $\mathrm{CO}$ peaks tend to be smaller, and there is a factor of 10 variation between the smallest and largest peaks. In many instances, there is no observable $\mathrm{CO}$ peak. In the aggressive mode, all 14 accelerations make substantial $\mathrm{CO}$ and peak to peak variation is a factor of two at most. Because particulate matter and carbon monoxide are correlated [5], the aggressive mode will produce correspondingly larger particulate bursts, leading to higher mass emissions of PM as observed. A comparison of emissions for the two laboratories for Bus 1010 is shown in Figure 5. When the CIFER driver drove Bus 1010 in a nonaggressive manner, emissions of $\mathrm{CO}$ and $\mathrm{PM}$ became very 
close to the WVU values. Real in-use driving is most likely more aggressive in nature as drivers freely accelerate to cruise speed.

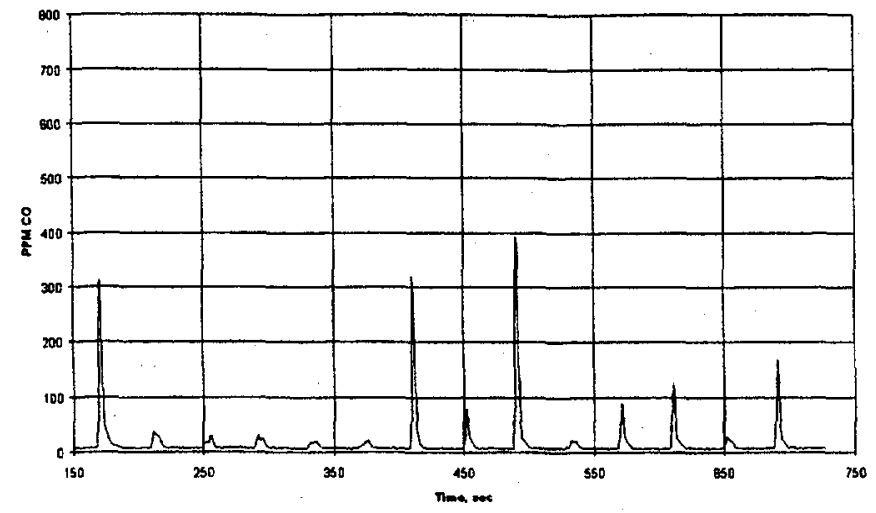

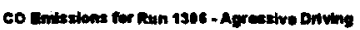

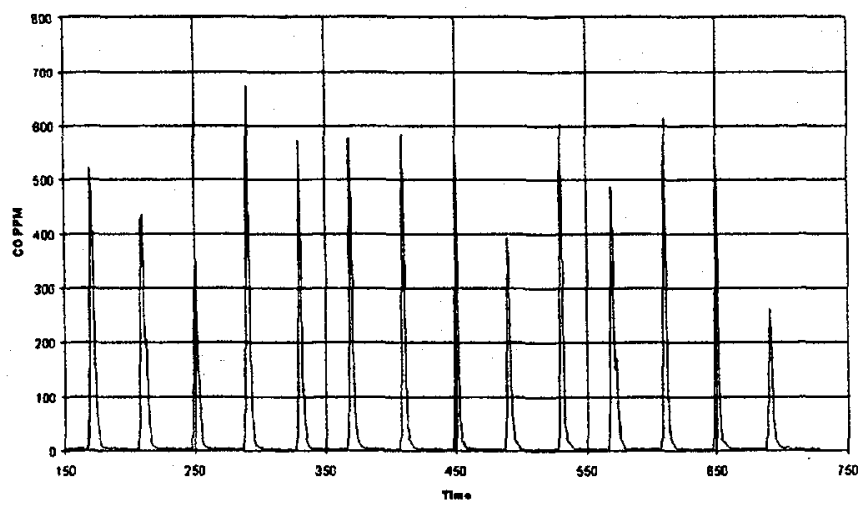

Figure 4. Comparison of real time, diluted exhaust $\mathrm{CO}$ concentration for non-aggressive (top) and aggressive (bottom) driving of the CBD cycle, diesel bus 1010 .

Bus 1010: Diesel Powered

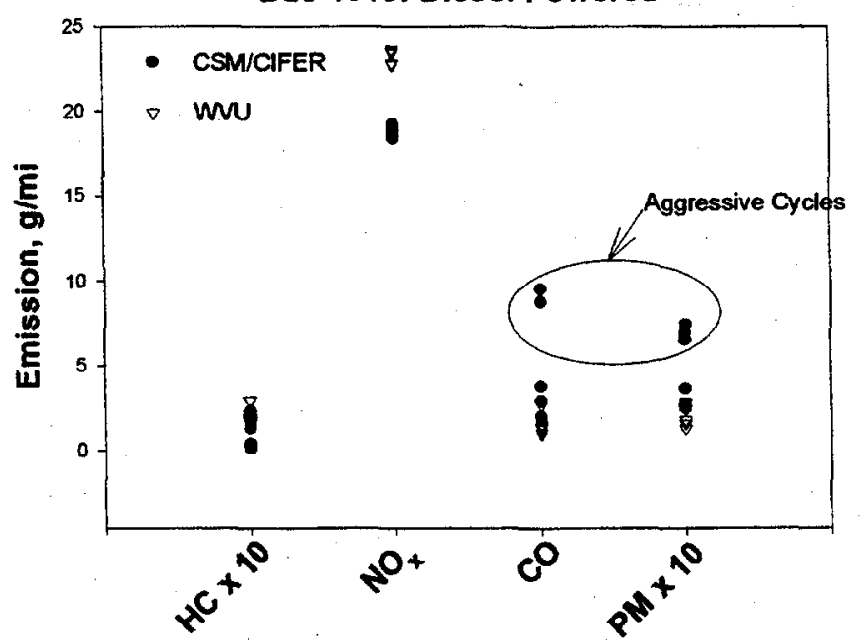

Figure 5. Comparison of chassis dynamometer emissions (CIFER) for bus 1010 .

The data in Figure 4 were generated on the CIFER dynamometer. However, equivalent results were also observed by WVU. Figure 6 shows a typical (non-aggressive) $\mathrm{CO}$ versus time trace for bus 1011 indicating great variability in $\mathrm{CO}$, with some of the accelerations generating essentially no $\mathrm{CO}$. The figure also includes a corresponding trace for
$\mathrm{NO}_{\mathrm{x}}$ showing that, for diesel, oxides of nitrogen are not as variable. Figure 7 shows a mass emissions comparison for aggressive and non-aggressive driving on the WVU dynamometer demonstrating the substantial effect of driving style on emissions of CO and PM.
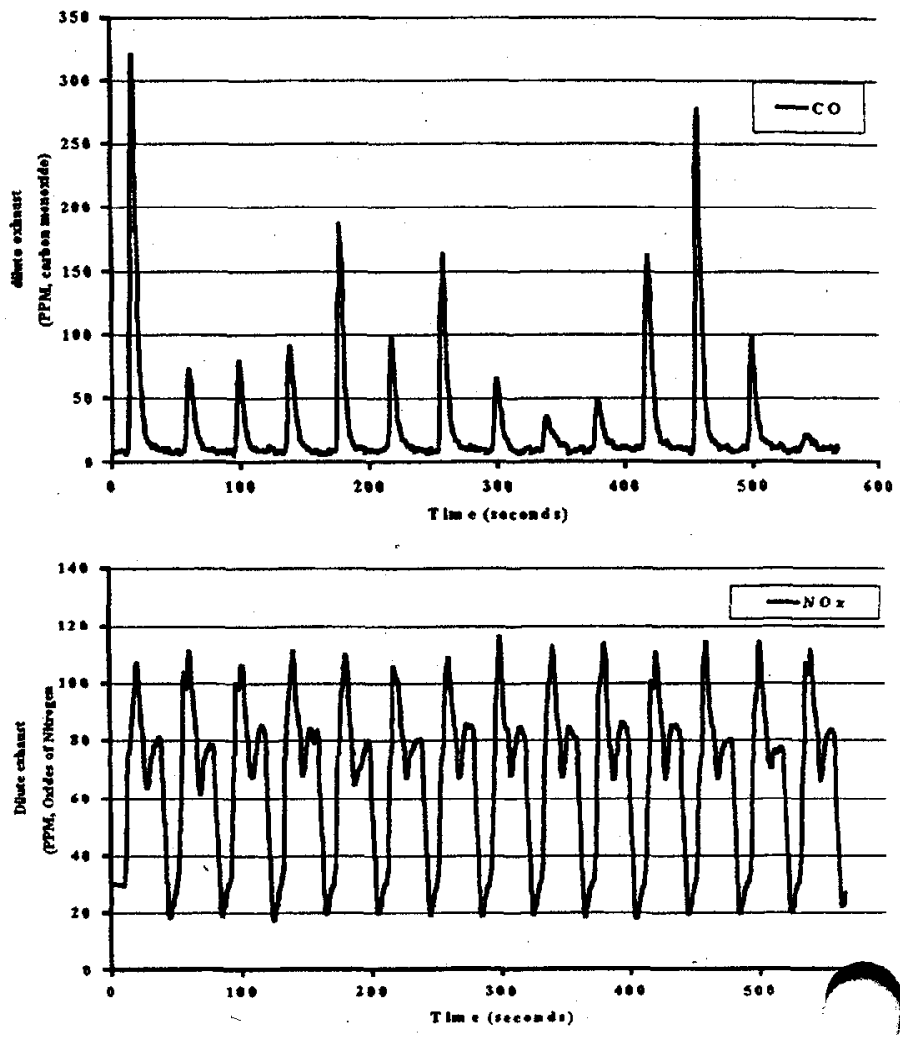

Figure 6. Continuous WVU $\mathrm{CO}$ and $\mathrm{NO}_{\mathrm{x}}$ data for diesel bus 1011 tested using the CBD cycle. Emissions are presented as parts per million, dilute exhaust.

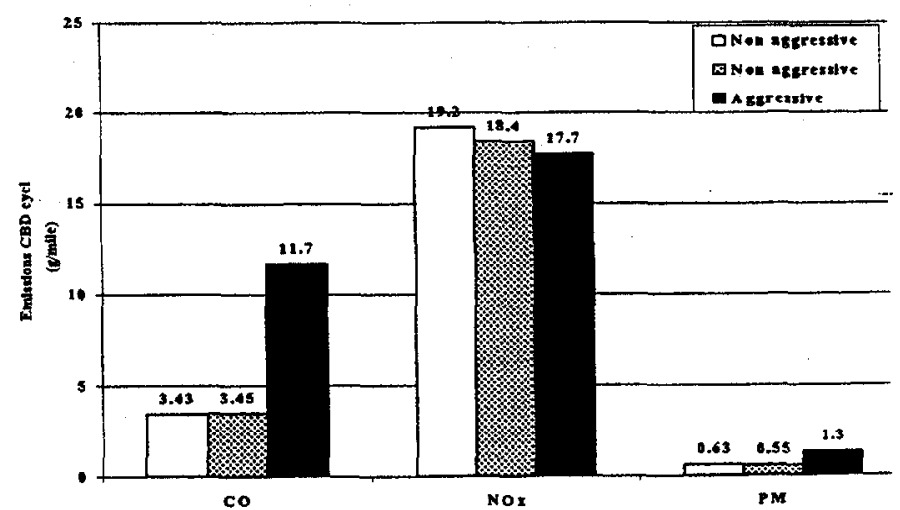

Figure 7. WVU laboratories emission results on diesel fueled bus 1011 exercised though the CBD cycle with aggressive and two separate non-aggressive acceleration tests on separate dates.

As noted for the $\mathrm{CNG}$ vehicles, emissions of $\mathrm{NO}_{\mathrm{x}}$ are generally higher for the CIFER tests than for the WVU tests. However, when bus 1015 was driven in a non-aggressive manner, $\mathrm{NO}_{\mathrm{x}}$ emissions became much closer, as shown in Figure 8. Typical lean burn spark ignited natural gas contru. strategies would cause $\mathrm{NO}_{\mathrm{x}}$ to react to high loading, in a similar fashion to the $\mathrm{CO}$ behavior in diesel engines. 
Bus 1015: CNG Powered

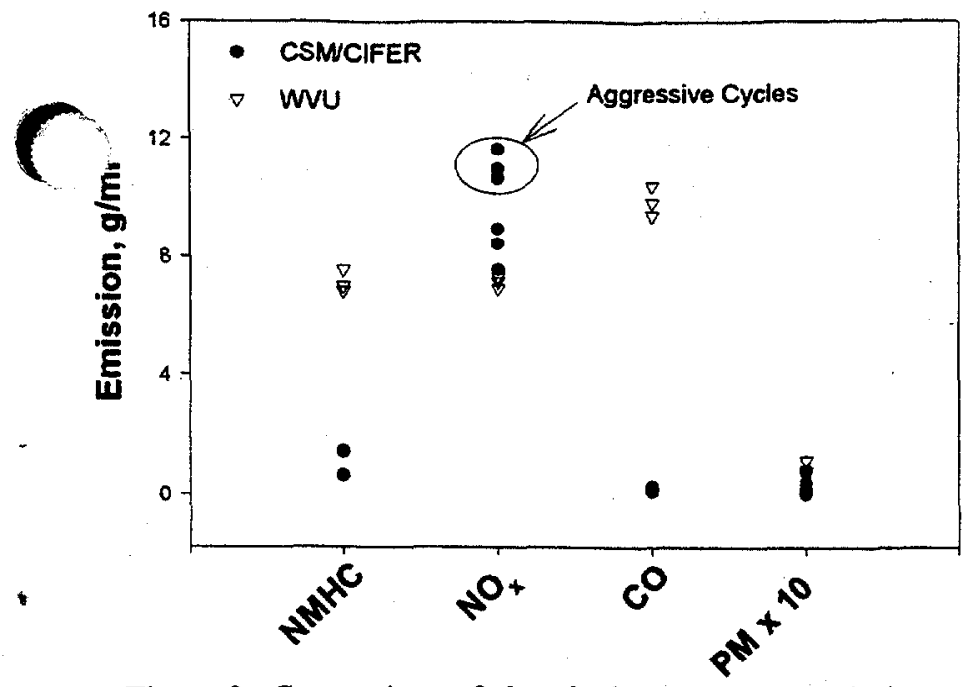

Figure 8. Comparison of chassis dynamometer emissions from Bus 1015 . Note this bus was tested with catalyst by CIFER and without catalyst by WVU.

FUEL ECONOMY. Based on testing at CIFER (aggressive acceleration), energy equivalent fuel consumption in $\mathrm{Btu} / \mathrm{mi}$ was on average $22 \%$ higher for the CNG fueled vehicles over the CBD cycle. At the WVU lab (nonaggressive acceleration), energy equivalent fuel consumption was on average $18 \%$ higher for the CNG fueled vehicles than for the diesel vehicles. If the slightly higher values for fuel consumption obtained by WVU for bus 1011 are considered outliers and excluded from the analysis, both laboratories find a $22 \%$ increase in energy equivalent fuel economy for $\mathrm{CNG}$ over diesel.

\section{DISCUSSION}

The implications of driving habit are demonstrated in Figure 9 where emission data for all three diesel buses are shown. The driver aggression/non-aggression effect is included in the carbon monoxide emission plotted on the $X$ axis. The $\mathrm{Y}$-axis shows $\mathrm{NO}_{\mathrm{x}}$ and particulate matter emissions. The $\mathrm{NO}_{\mathrm{x}}$-particulate matter tradeoff is evident in the plot. $\mathrm{NO}_{\mathrm{x}}$ falls as PM increases. PM increases linearly with $\mathrm{CO}$ emission and the slope is approximately 0.75 . A range of 5 is observed for $\mathrm{PM}$ emissions while $\mathrm{NO}_{\mathrm{x}}$ decreases by about $20 \%$. As Figure 9 shows, emissions for all three diesel buses fall on the same plot indicating that the results from the two laboratories follow the same trends. The engines from all three buses are performing consistently although emissions do depend on driver behavior.
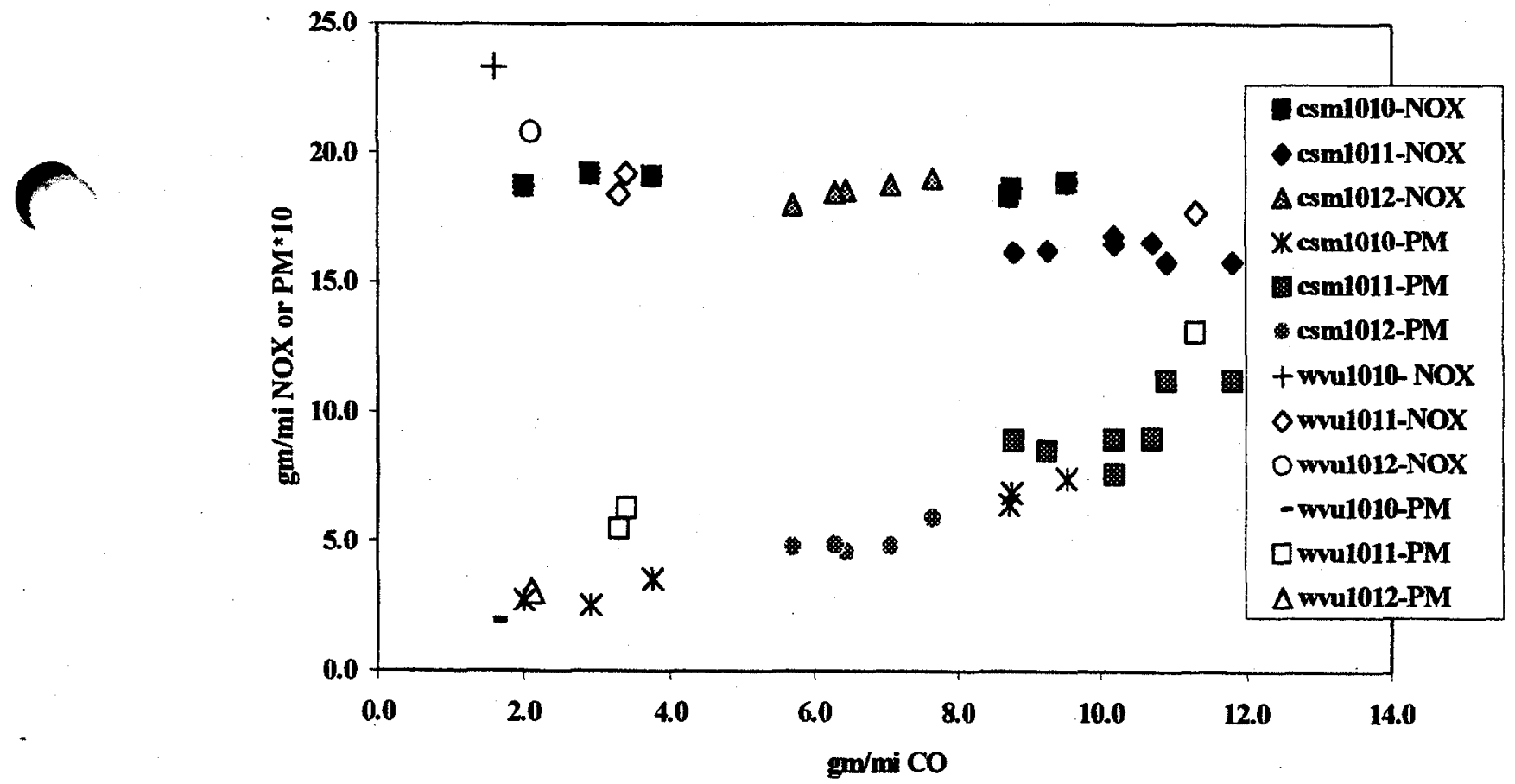

Figure 9. $\mathrm{NO}_{\mathrm{x}}$ and $\mathrm{PM}$ emissions plotted against $\mathrm{CO}$ emissions (a surrogate for driver aggression) for all three diesel vehicles.

\section{QUANTITATIVE COMPARISON OF CIFER AND} WVU LABORATORIES. Because of the extreme vehicle variability caused by driver technique, comparison of the diesel bus emissions measurements from the two laboratories cannot be made directly. To compare WVU data with CIFER data, the CIFER data sets for $\mathrm{NO}_{\mathrm{x}}$ and PM were regressed against $\mathrm{CO}$ and a best fit least squares line was obtained. The unction used was as follows:

$$
\operatorname{Ln}\{\text { Emission, } g / \text { mile }\}=\alpha * \mathrm{CO}, \mathrm{g} / \mathrm{mile}+\beta
$$

This model gave a reasonable fit for $\mathrm{NO}_{\mathrm{x}}$ and an excellent fit for PM. The residuals for both the $\mathrm{PM}$ and $\mathrm{NO}_{\mathrm{x}}$ models suggest that no outliers exist in the data set. The PM residuals suggest purely random variation. The $\mathrm{NO}_{x}$ data suggest that some small systematic error might exist but the residuals are so small that the observation is of no consequence. Expanding the log model to a quadratic in CO for $\mathrm{NO}_{x}$ and $\mathrm{PM}$ resulted in no improvement in explanation of variance. 
The relevant statistical data for the fits are given in Table 5. In the analysis, the effect of error in both $\mathrm{CO}$ and $\mathrm{NO}_{\mathrm{x}}$ or PM was considered following Mandel [12]. It was found that that the classical least squares treatment of the data was adequate. Figures 10 and 11 present a comparison of the West Virginia University emissions with the correlation of CIFER emissions and their $99 \%$ confidence limits. Except for the lowest $\mathrm{CO}$ emission points, agreement for $\mathrm{NO}_{x}$ emissions is quantitative. For vehicles 1010 and 1012, the West Virginia PM data agree well with the CIFER data. The remaining PM data for bus 1011 are offset higher by 0.3 grams/mile.
Table 5. Statistical parameters for regression model of $\mathrm{NO}_{x}$ and PM as a function of $\mathrm{CO}, \mathrm{CIFER}$ data for three diesel buses.

\begin{tabular}{|c|c|c|}
\hline Parameter & NO Fit & PM Fit \\
\hline Observations & 22 & 22 \\
\hline Adjusted R Square & 0.647 & 0.956 \\
\hline Intercept & 3.027 & -1.637 \\
\hline Slope & -0.01986 & 0.1454 \\
\hline t-Stat -Intercept & 103.59 & -26.08 \\
\hline t-Stat- Slope & -6.287 & 21.434 \\
\hline
\end{tabular}

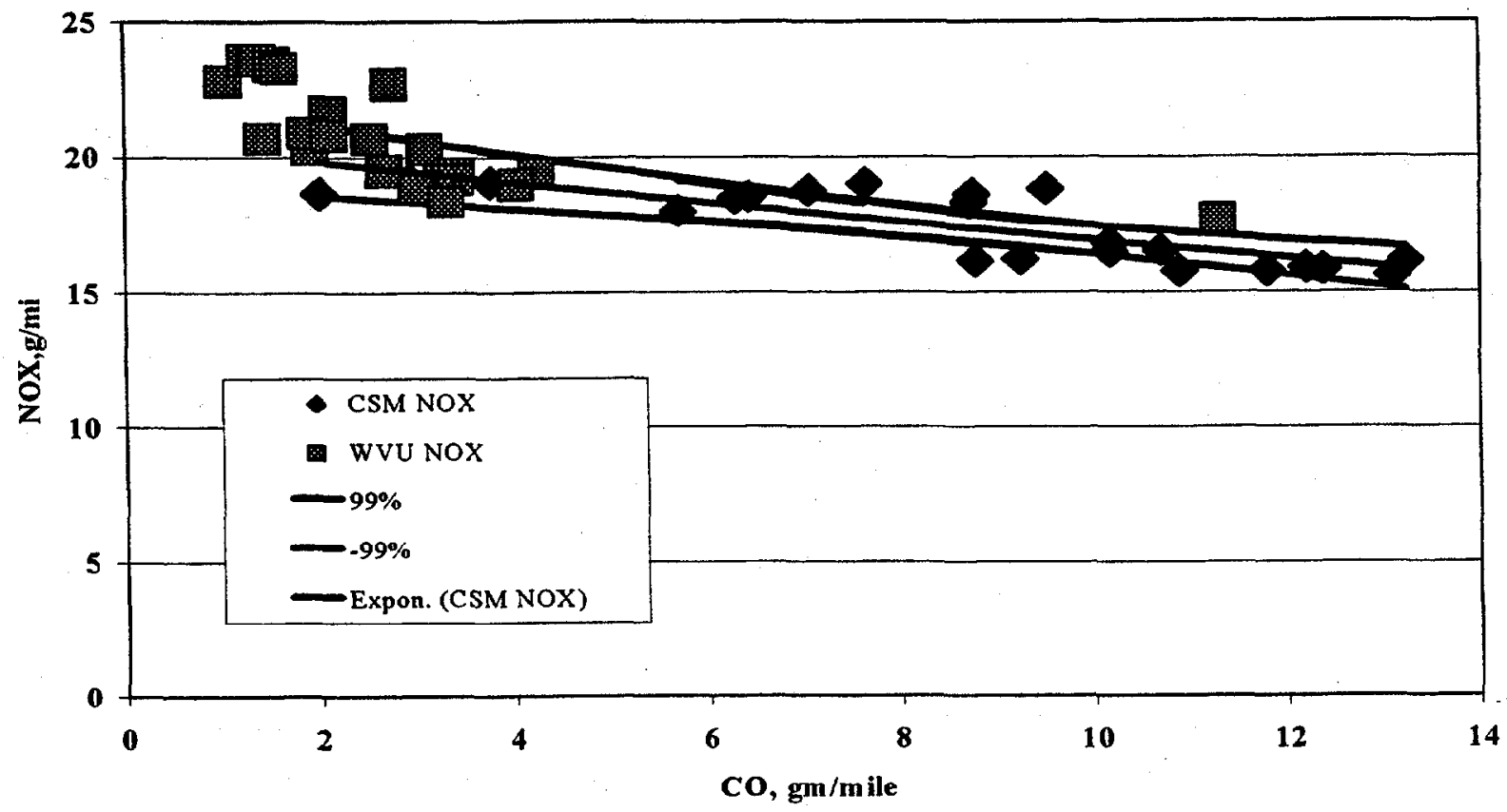

Figure 10. Comparison of WVU $\mathrm{NO}_{\mathrm{x}}$ emissions with empirical correlation of CIFER $\mathrm{NO}_{\mathrm{x}}$ emissions.

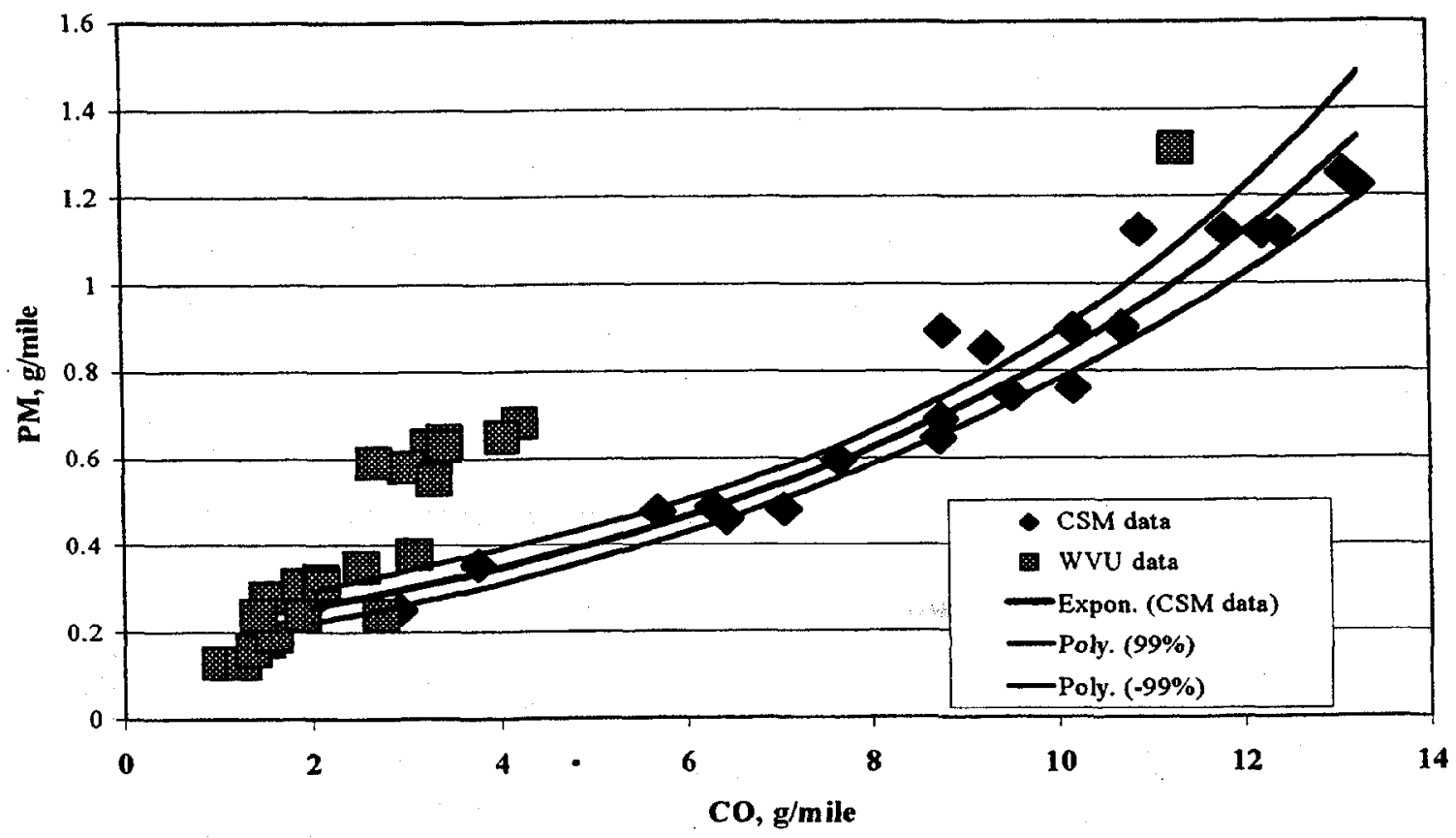

Figure 11. Comparison of WVU PM emissions with empirical correlation of CIFER PM emissions. 
EMISSIONS MMPLICATIONS OF DRIVER AGGRESSION. Emissions of $\mathrm{NO}_{\mathrm{x}}$ and $\mathrm{PM}$ were calculated in grams per brake horsepower hour to make a comparison with the 1997 engine emissions standard although, it is -knowledged that the duty cycles for the CBD and for the tification standard do not match. For instructional purposes, we assumed an average fuel efficiency of 0.35 pounds of diesel per brake horsepower hour. Based upon a typical observed $\mathrm{CO}_{2}$ emission rate of 1820 grams/mile, 3.59 bhp-h/mile are generated. At 2 grams/mile of $\mathrm{CO}$, the PM emission corresponds to 0.07 grams per brake horsepower hour, while the $\mathrm{NO}_{x}$ emission is 5.43 grams per brake horsepower hour. For transit buses, the $\mathrm{NO}_{\mathrm{x}}$ and $\mathrm{PM}$ standards are 5 and 0.1 grams per brake horsepower hour respectively for these 1997 model year engines. This suggests that driving the vehicle in the non-aggressive mode produces emissions consistent with the 1997 standards. On the other hand, aggressive driving produces considerably more PM and somewhat lower $\mathrm{NO}_{\mathrm{x}}$. For the worst $\mathrm{CO}$ emission observed, the emissions are estimated to be 0.35 grams per brake horsepower hour and 4.45 grams per brake horsepower hour of PM and $\mathrm{NO}_{\mathrm{x}}$, respectively. The PM emission in this mode is no different than under the pre-1991 heavy-duty engine standard.

This observation is important because it demonstrates a lack of robustness in emission controls such that varying levels can occur due to minor differences in driving pattern. This suggests that emissions benefits expected based on tighter standards for new engines might not translate to lower

in-use emissions. Because there is not a significant difference fuel economy, the observation is probably not a . anifestation of "cycle beating". More likely, it is a result of non-linearity in the complex electronics employed by the OEM to satisfy simultaneously the environmental regulations and the customers' performance and economy needs.

A similar analysis can be made for the CNG engines. Assuming a typical fuel economy of $10,000 \mathrm{Btu} / \mathrm{bhp}-\mathrm{h}$ [13], and using as a typical value $28,300 \mathrm{Btw} / \mathrm{mile}$ fuel consumption, $2.83 \mathrm{bhp}-\mathrm{h} / \mathrm{mile}$ is generated. Comparing the aggressive and non-aggressive driving of Bus 1015, this corresponds to $2.94 \mathrm{~g} / \mathrm{bhp}-\mathrm{h}$ of $\mathrm{NO}_{\mathrm{x}}$ and $0.65 \mathrm{~g} / \mathrm{hhp}$-h of NMHC in the non-aggressive mode. In the aggressive mode $3.92 \mathrm{~g} / \mathrm{bhp}-\mathrm{h}$ of $\mathrm{NO}_{\mathrm{x}}$ and $0.60 \mathrm{~g} / \mathrm{bhp}-\mathrm{h}$ of NMHC are emitted. The EPA LEV standard is $3.8 \mathrm{~g} / \mathrm{bhp}-\mathrm{h}$ for $\mathrm{NO}_{\mathrm{x}}$ and NMHC combined. This value is 3.59 for non-aggressive driving and 4.52 for aggressive driving, and thus the LEV standard may be exceeded in the aggressive driving mode.

\section{CONCLUSIONS}

The CIFER and WVU laboratories tested the six Go Boulder/RTD SKIP buses, three powered by Cummins diesel engines and three by Cummins CNG engines. Prior to this testing, several checks were made to insure that procedures and analytical methods were consistent between the two laboratories. Based on these checks, analyses of diluted haust composition yield identical results. Differences oetween emissions measured by the laboratories will therefore be caused by differences in the chassis dynamometer setups and procedures.

Emissions test results allow a comparison of nearly identical diesel and $\mathrm{CNG}$ powered vehicles. It was found that for CNG buses PM and CO emissions are only a small fraction of the PM emissions from these diesel vehicles. Diesel PM averaged approximately $0.7 \mathrm{~g} / \mathrm{mi}$. while CNG PM was well below $0.1 \mathrm{~g} / \mathrm{mi}$. Diesel $\mathrm{CO}$ averaged $8.2 \mathrm{~g} / \mathrm{mi}$. and CNG averaged less than $0.3 \mathrm{~g} / \mathrm{mi}$. Emissions of $\mathrm{NO}_{\mathrm{x}}$ are also substantially lower for the $\mathrm{CNG}$ powered buses. $\mathrm{NO}_{\mathrm{x}}$ emissions averaged approximately $18.4 \mathrm{~g} / \mathrm{mi}$. for diesel and $11.2 \mathrm{~g} / \mathrm{mi}$. for CNG. BTU based fuel consumption was on average $22.7 \%$ higher for the CNG fueled vehicles over the CBD cycle.

The WVU laboratory is in agreement with CIFER laboratory on the findings that CNG, PM and CO emissions are a small fraction of the PM emissions from the diesel vehicles. WVU found that the (Non-aggressive driving), diesel PM averaged approximately $0.38 \mathrm{~g} / \mathrm{mi}$. while CNG PM was well below $0.1 \mathrm{~g} / \mathrm{mi}$. for the two buses equipped with catalyst and at $0.1 \mathrm{~g} / \mathrm{mi}$. for bus 1015 without the catalyst. Also diesel $\mathrm{CO}$ averaged $2.38 \mathrm{~g} / \mathrm{mi}$. while the CNG with catalyst averaged $0.39 \mathrm{~g} / \mathrm{mi}$. CNG bus 1015 without the catalyst had CO emissions higher than the diesel buses at 8.25 $\mathrm{g} / \mathrm{mi}$. This shows the necessity of a catalyst on the NG fueled buses.

Emissions of $\mathrm{NO}_{x}$ are also substantially lower for the CNG powered buses. $\mathrm{NO}_{\mathrm{x}}$ emissions averaged approximately $20.6 \mathrm{~g} / \mathrm{mi}$. for diesel and $8.7 \mathrm{~g} / \mathrm{mi}$. for CNG. Energy equivalent fuel consumption was on average $17.8 \%$ higher for the CNG fueled vehicles over the CBD cycle.

A comparison of emissions measurements between the two laboratories indicates very similar, though not identical results. The laboratories have different driver's aid equipment and this tends to cause the driver to drive the cycle with a different technique on the CIFER dynamometer (aggressive) versus the WVU dynamometer (non-aggressive). Small differences in driver aggression and the manner in which the vehicles are accelerated leads to large changes in emissions of $\mathrm{CO}$ and PM for the diesel vehicles, and significant changes in emissions of $\mathrm{NO}_{\mathrm{x}}$ for the $\mathrm{CNG}$ vehicles. Bus 1010 was purposely driven in both driving modes and it was observed that aggressive driving could increase $\mathrm{CO}$ by more than a factor of 3 and PM by more than a factor of 2 , relative to nonaggressive driving. Similarly, CNG bus 1015 was driven in both modes resulting in a more than $30 \%$ increase in $\mathrm{NO}_{x}$ relative to non-aggressive driving. The finding that driver technique can have a large effect on emissions is one of the major findings of this study, although not originally a study objective. Emissions of $\mathrm{CO}$ can be used as a surrogate for driver aggression for the diesel vehicles. Agreement between the CIFER and WVU laboratories is good, when PM and $\mathrm{NO}_{\mathrm{x}}$ data are correlated with $\mathrm{CO}$ emissions. 


\section{ACKNOWLEDGEMENTS}

The WVU authors are grateful to the U.S. Dept. of Energy, Office of Transportation Technologies, for support of this program, and the field crew of the transportable laboratory for their contribution to this paper. The CIFER authors acknowledge the support of the U.S. Dept. of Energy, National Renewable Energy Laboratory (Contract No. ACO8-18126-01) and the Natural Fuels Corporation of Denver, Colorado.

\section{CONTACT INFORMATION}

Contact Dr. Nigel Clark at nclark@wvu.cdu or (304)

293-3111 ext. 2311 and Dr. Robert

McCormick at rlmccorm@mines.edu or (303) 273-3967.

\section{REFERENCES}

1. Kittleson, D.B. and Johnson, J.H., "Variability in Particulate Emissions Measurements in the Heavy Duty Transient Test," Society of Automotive Engineers Tech. Pap. No. 910738, 1991

2. Clark, N.N., Gautam, M., Boyce, J.A., Wang, W.G., and Lyons, D.W., "Emissions Performance of Natural Gas and Diesel Fueled School Buses with Cummins 8.3 liter Engines", ASME Internal Combustion Engine Division Spring Conf., Columbus, In., 1999.

3. Clark, N.N., Lyons, D.W., Rapp, B.L, Gautam, M., Wang, W.G., Norton, P., White, C. and Chandler, C., "Emissions from Trucks and Buses Powered by Cummins L-10 Natural Gas Engines", Society of Automotive Engineers Tech. Pap. No. 981393 (1998).

4. Clark, N.N., Lyons, D.W., Bata, R.M., Gautam, M., Wang, W.G., Norton, P., and Chandler, K., "Natural Gas and Diesel Transit Bus Emissions: Review and Recent Data", Society of Automotive Engineers Tech. Pap. No. 973203 (1997).

5. Yanowitz, J., Graboski, M.S., Ryan, L.B.A., Alleman, T.L. and McCormick, R.L., "Chassis Dynamometer Study of Emissions from 21 In-Use Heavy-Duty Diesel Vehicles", Environ. Sci. Technol. in press.

6. Clark, N.N. and Lyons, D.W., "Class 8 Truck Emissions Testing: Effects of Test Cycles and Data on Biodiesel Operation", American Society of Agricultural Engineers Meeting, Orlando, Fl, July 1998. ASAE Paper 986082

7. Clark, N., M. Gautam, R. Bata, W. Wang, J. Loth, G. M. Palmer and D. Lyons. "Design and Operation of a New Transportable Laboratory for Emissions Testing of Heavy Duty Trucks and Buses," Heavy Vehicle Systems, International Journal of Vehicle Design, Vol. 2, Nos. 3/4, pp.308-322, 1995
8. M. Gautam. N. Clark D. Lyons, T. Long Jr., A. Howell, J. Loth, G. Palmer, W. Wang and R. Bata. "Design Overview of a Heavy Duty Mobile Vehicle Emissions Testing Laboratory," Proceedings of the ASME Annual Meeting, Atlanta, GA, December 1-6, 1991. Also in Advanced Automotive Technology, DE-Vol. 40, ASM Special Publication, 1991

9. Urban, C.M. "Dynamometer Simulation of Truck and Bus Road Horsepower for Transient Emissions Evaluations" Society of Automotive Engineers Tech. Pap. No. 840349 (1984).

10. McCormick, R.L.; Ross, J.D. and Graboski, M.S. "Effect of Several Oxygenates on Regulated Emissions from Heavy-Duty Diesel Engines" Environ. Sci. Technol. 1997, 31,1144 .

11. Russell, A., Milford, J., Bergin, M.S., McBrice, S., McNair, L., Yang, Y., Stockwell, W.R., and Croes, B., "Urban Ozone Control and Atmospheric Reactivity of Organic Gases" Science_1995, 269, 491 .

12. Mandel, J. The Statistical Analysis of Experimental Data, p 288, Dover Publications, Inc, New York, New York, 1984.

13. Graboski, M.S., R.L. McCormick, A.W. Newlin, D.L. Dunnuck, M.M. Kamel, W.D. Ingle, "Effect of.Fuel Composition and Altitude on Regulated Emissions from a Lean-Burn, Closed Loop Controlled Natural Gas Engin Society of Automotive Engineers Paper No., 971707 (1997). 
Average CBD Emissions Test Results from CIFER Chassis Dynamometer.

\begin{tabular}{|c|c|c|c|c|c|c|c|c|c|}
\hline Vehicle & $\begin{array}{c}\text { \# of } \\
\text { Cycles }\end{array}$ & Comments & $\begin{array}{c}\text { THC } \\
(\mathbf{g} / \mathbf{m i} .)\end{array}$ & $\begin{array}{c}\text { NOx } \\
\text { (g/mi.) }\end{array}$ & $\underset{(\mathrm{g} / \mathrm{mi} .)}{\mathrm{CO}}$ & $\underset{(\mathrm{g} / \mathrm{mi} .)}{\mathrm{CO2}}$ & $\underset{(\mathrm{g} / \mathbf{m i} .)}{\mathbf{P M}}$ & $\begin{array}{c}\text { NMHC } \\
(\mathrm{g} / \mathrm{mi} .)\end{array}$ & $\begin{array}{l}\text { Fuel Economy } \\
\text { (Btu/mi.) }\end{array}$ \\
\hline Bus 1010: diesel & 3 & Non aggressive & 0.18 & 18.99 & 2.89 & 1787 & 0.29 & -- & 22971 \\
\hline Bus 1010: diesel & 3 & Aggressive & 0.09 & 18.60 & 9.00 & 1853 & 0.69 & -- & 23812 \\
\hline Bus 1011: diesel & 11 & Aggressive & 0.18 & 16.12 & 11.18 & 1783 & 1.02 & -- & 22935 \\
\hline Bus 1012: diesel & 5 & Aggressive & 0.14 & 18.56 & 6.62 & 1771 & 0.50 & - & 22767 \\
\hline Bus 1013: CNG & 3 & Aggressive & 16.10 & 14.80 & 0.28 & 1689 & 0.024 & 2.30 & 28820 \\
\hline Bus 1014: CNG & 7 & Aggressive & 20.04 & 9.06 & 0.34 & 1616 & 0.015 & 2.19 & 27780 \\
\hline Bus 1015: CN & 3 & Non Aggressive & 18.05 & 8.33 & 0.19 & 1640 & 0.044 & 1.83 & 28188 \\
\hline Bus 1015: CNG & 3 & Aggressive & 17.27 & 11.09 & 0.12 & 1655 & 0.006 & 1.71 & 28457 \\
\hline
\end{tabular}

" $\mathrm{CNG}$ vehicles are regulated based on NMHC rather than THC. For the LEV vehicles tested here the standard is for $\mathrm{NMHC}^{\text {and }} \mathrm{NO}_{\mathrm{x}}$ combined.

\begin{tabular}{|c|c|c|c|c|c|c|c|c|c|}
\hline Vehicle & $\begin{array}{c}\text { \# of } \\
\text { Cycles }\end{array}$ & $\begin{array}{l}\text { Average CBD Emissi } \\
\text { Comments }\end{array}$ & $\begin{array}{l}\text { st Results } \\
\text { THC } \\
\text { (g/mi.) }\end{array}$ & $\begin{array}{c}\text { from W } \\
\text { NOx } \\
(\mathrm{g} / \mathrm{mi} .)\end{array}$ & $\begin{array}{l}\text { U Chas } \\
\text { Co } \\
\text { (g/mi. })\end{array}$ & $\begin{array}{c}\text { is Dynan } \\
\text { CO2 } \\
\text { (g/mi.) }\end{array}$ & $\begin{array}{c}\text { ometer. } \\
\text { PM } \\
\text { (g/mi.) }\end{array}$ & $\begin{array}{l}\text { NMHC } \\
(\mathrm{g} / \mathrm{mi} .)\end{array}$ & $\begin{array}{l}\text { Fuel Economy } \\
\text { (Btu/mi.) }\end{array}$ \\
\hline Bus 1010: diesel & 6 & Non aggressive & 0.20 & 23.3 & 1.57 & 1760 & 0.19 & - & 22527 \\
\hline Bus 1011: diesel & 6 & Non aggressive & 0.24 & 19.2 & 3.43 & 1950 & 0.63 & -- & 24995 \\
\hline Bus 1011: diesel & 2 & Aggressive & 0.36 & 17.7 & 11.3 & 1942 & 1.45 & -- & 25056 \\
\hline Bus 1012: diesel & 6 & Non-aggressive & 0.31 & 20.8 & 2.15 & 1743 & 0.31 & -- & 22319 \\
\hline Bus 1013: CNG & 6 & Non-aggressive & 10.5 & 11.0 & 0.25 & 1575 & 0.020 & 0.36 & 27420 \\
\hline Bus 1014: CNG & 6 & Non-aggressive & 14.6 & 6.78 & 0.53 & 1609 & 0.004 & 0.71 & 28203 \\
\hline Bus 1015: CNG & 6 & Non Aggressive & 19.5 & 8.42 & 8.25 & 1495 & 0.10 & 2.11 & 26693 \\
\hline
\end{tabular}

